\title{
Identifying Small and Medium Enterprise Smart Entrepreneurship Training Framework Components using Thematic Analysis and Expert Review
}

\author{
Anis Nur Assila Rozmi ${ }^{1}$, Puteri N.E. Nohuddin ${ }^{2}$ \\ Institute of IR4.0 \\ Universiti Kebangsaan Malaysia \\ Bangi, Malaysia \\ Universiti Kuala Lumpur \\ British Malaysian Institute \\ Gombak, Selangor
}

\author{
Abdul Razak Abdul Hadi ${ }^{3}$ \\ Universiti Kuala Lumpur Business School \\ Kuala Lumpur, Malaysia \\ Mohd Izhar A. Bakar ${ }^{4}$ \\ UniKL British Malaysian Institute \\ Gombak, Malaysia
}

\begin{abstract}
Small and Medium Enterprises (SMEs) today are facing a competitive business environment, in a complex and rapidly changing environment. For that technology is seen as a mediator capable of transforming SMEs to greater heights in an amid and vigorous pace of a borderless world. The agenda of SMEs to generate national income as well as to create more employment opportunities has made the government much focused in providing improvements in business opportunities to SMEs to boost the country's economic growth. To ensure that the SME owners sustain their business, they should be able to adapt the use of the internet as a key component in designing new business model values, customer experiences and internal capabilities that support the key operations. However, there are still some SME owners who do not leverage on the use of Information and Communication Technology (ICT) in their business operations. This study interviewed eight SME owners who operated their businesses in Kuala Lumpur and Selangor to identify a list of most important business training courses needed for SMEs in Malaysia. The data was analyzed using Thematic Analysis method and it was found that there are five main components of courses in SMEs, namely, Business Management, Sales and Marketing, Accounting and Finance, ICT and Technology, and Production and Operations. As a result of this Thematic Analysis study, researchers have developed a smart entrepreneurship training framework related to the five components and produced a system called, the Malaysian SMEs Psychometric Test or U-PPM which has been reviewed and endorsed by the respective panels of experts. This proposed framework is important for SME owners and management and also the government and stakeholders, when making the correct decisions in selecting business training courses as well as to increase ICT and digital technologies usage in providing a positive impact to all SMEs in Malaysia.
\end{abstract}

Keywords-Small Medium Enterprise (SME); business owner; thematic analysis method; expert panel; Information and Communication Technology (ICT); course selection system; smart entrepreneurship training framework

\section{INTRODUCTION}

Entrepreneurship has become an important agenda in order to build a more sustainable national future [38] [77].
Entrepreneurial development approaches improved modern economy [44] and provides spaces in creating employment opportunities [10]. The importance of this field has been applied at the university level [49] with the cooperation of both government and private sectors. There are various programs, training sessions, courses, workshops, seminars, and entrepreneurship education activities that have been implemented to encourage entrepreneurs to obtain formal knowledge and education in the field of entrepreneurship, to face challenges in today's sophisticated business models.

In order to realize the government's expectations to produce more entrepreneurs in the country, various initiatives have been made. Courses and training sessions have been conducted to make SMEs more competitive, provide a simple service and customer support system. SMEs that have been operating for a long time have lots of experience in running their business, but they sometimes face difficulties in several aspects such as internal management, marketing capabilities, technological capabilities, access to knowledge networks, and finance [74].

Thus, it is important for the training providers to implement standards and models of entrepreneurship-based education as well as to develop courses and skills that can be used by the entrepreneurs. This is because the role of training and courses is to help SME entrepreneurs and staff to enhance their performance [35]. In addition, the skills and knowledge are required for them to perform their functions. Entrepreneurs, especially micro-sized businesses are encouraged to find relevant courses to improve their business and their employee's performance. They should be given these trainings and courses so that they can be multi task entrepreneurs.

Among the courses and training activities that are essential to SME owners and staff are those covering management skills [51], leadership [27], communication [63], technical skills [39] [48], according to the field of enterprise, digital marketing [24] [25], and financial management skills [15] [59]. Training is required to ensure that the employees are able to perform their tasks in order to meet the objectives of the enterprise. Hence, 
this training needs to be planned carefully in order for it to have an impact on the success of the business.

To ensure that the correct selection is done properly, this study has developed a Psychometric Test model for SMEs using the Thematic Analysis (TA) method. The construction of this model has been evaluated and reviewed by a group of experts from the government and private sectors in the areas of Business Management, Digital Marketing, Accounting, Business Operations, and Language.

\section{LITERATURE REVIEW}

\section{A. Impact of Courses on Organizations}

Entrepreneurs' level of education contributed to the performance and development of the business organization [84]. This happens because they did not emphasize the importance of training and improving knowledge and skills. The lack of skills and access to finance, knowledge of marketing, infrastructure and information had made it difficult to achieve success [40]. Therefore, SME owners need to get training and education at an earlier stage for the training programs to have a greater impact on enterprises [50].

The impact of entrepreneurial training on businesses is through a proactive attitude, innovation, and willingness to take any risks [4]. Additionally, SME entrepreneurs who participate in entrepreneurship training and courses experience a shortterm improvement in entrepreneurial self-efficacy [28]. By choosing the right course, SME owners are able to improve their business skills [58]. Employees and SME owners who attended short-term courses can see results of their self-skills training attended by business entrepreneurs and employees [72]. Such impacts had an increase in sales revenue and profits, helped broaden the mind, and inculcated in the owners and employees the ability to take strong personal initiatives and to have perseverance, which further improved business practices.

The positive impacts of such courses were continued to be discussed in the study by [16] where they concurred that the effectiveness of such training is seen to be a valuable investment. In addition, the positive impact of course involvement can also be detected through an increase in the income as well as improvement in the financial performance of the enterprises [41].

The disposition of unskilled and unknowledgeable workers in enterprises is seen as a risk in losing business opportunities [46] other than having the tendency of becoming bankrupt [73]. On the other hand, employees who have gone through self-improvement courses and training provide a positive impact on the job, showing improvements in their performance and job quality, in addition to being motivated and loyal to the enterprise [30]. Therefore, SMEs should seize the available opportunities and take the necessary initiatives to improve and enhance the employees' knowledge and skills to boost competitiveness [69]. In addition, after they have undergone the courses and trainings, it would affect the growth, profitability and job creation in the enterprise [56].

\section{B. Courses Options for Organizations}

The Part of SME operations include management, finance, sales and marketing, ICT and technology, and production and operations, which are also listed as elements that determine the success of an SMEs. Thus, courses and training that act as a medium for knowledge enhancement are seen to improve the performance of the sales force [16]. A decade ago, course selection was made based on performance competency models that built individual competencies [23]. Additionally, the competency model by [75] has been used as an instrument in providing a skilled workforce and meeting job needs.

There are various courses that can be studied by every SME employee in order to boost their skills or knowledge to improve their job performance. These courses include orientation training, internal and external company management training. The designed courses usually depend on the needs of SMEs [22], financial estimates [26] that can be spent and other priorities focused on by the SMEs. Before creating training contents, training providers need to evaluate the training needs so that the program meets the needs of the organization [47].

Other management functions had been prioritized such as accounting, marketing, finance, and production [50]. Therefore, these designed courses need to be holistic in nature, where the knowledge gained can be applied in the daily work of the employees, and it would also help in improving their work performance. Seven key areas are important for SMEs, and among the four courses that can be fitted and have impacts onto the training system in Malaysian SMEs are organizational management, sales and marketing, finance and accounting, and business planning [36].

Business Management courses are very important for owners in training individuals that they believe can lead the organization and other employees [43]. Among the topics covered in this organizational management course are leadership skills, personal skills such as how to motivate and delegate, development of industry and market analysis, operations planning, human resource management, developing sales strategies, and developing financial foundations, analysis and systems for start-ups. The goal of the course is to boost productivity, which is one of the core values of an organization.

According to [83], Human Resource Management (HRM) covers human resource planning, training, performance management, compensation management, safety, and health and employee relations. Good HRM can improve organizational performance by contributing to employees, customers, innovation, and productivity satisfaction. However, for small businesses such as SMEs, the importance of a new management approach is seen as a success if it can manage teamwork, job flexibility, and performance appraisal. SME owners need to understand the various management practices and the importance of staff training on SME performance.

Every enterprise requires the incorporation of digital marketing strategies to enhance sales [32] in today's economy. Therefore, a digital marketing course is seen as a holistic course because it is one of the best transformation platforms for businesses today. SMEs running online businesses need to implement digital marketing strategies that help online users to see them. Digital marketing is important to small businesses because it helps to further sales at a lower cost [71]. 
There are many benefits of digital marketing such as growing the business, cost effectiveness, ease of getting targeted with larger volume, availability of an exceptional marketing platform, ease of updating products or services, and ease of customer access to impart information on products or services [31] [76]. Digital marketing through social media, search engines, emails, contents, videos, infographics, photos, podcasts, e-books and newsletters can serve as a platform to potential customers who seek for products and services. Information technology has changed our lives and is now transforming traditional marketing methods into digital marketing. This course provides an in-depth focus on the application of marketing principles in the process of implementing marketing functions in new enterprises, including distribution channels, pricing strategies, promotion through social media, location, direct and indirect sales methods, consultation, customer management, and customer service.

This course provides an in-depth focus on the application of principles from accounting and finance courses, including applied activities such as earning, managing, and administering cash. In terms of specific competencies, it explores the use of financial software, as well as income development, income statements, balance sheets, and cash flow statements for commencement, together with their use in evaluating and managing an organization's finances, especially at an early stage. Financial knowledge is related to the managers' level of confidence in managing an enterprise [13].

Finance is the catalyst in economic growth and development in SMEs [2]. Therefore, it is important for every SME owner to participate in financial and accounting training programs, to acquire the knowledge of finance, financial attitudes, and financial behaviour, for it will have a positive impact on every financial step and financial access of the SME. Additionally, SME owners will be able to understand their financial situation better and plan their future finances and make accurate financial decisions as well as improve their level of financial access.

It is essential for employees to acquire the technologyrelated courses in regard to the technical aspects while working [33]. In terms of retails, it is insightful for employees to have knowledge on computers whilst communicating with customers. From a sales point of view, to be knowledgeable in technology is crucial to get new customers other than maintaining data of the existing customers. As for office management, technology knowledge has a basic usage in managing customers' data [65].

Technology has now changed the way customers access and obtain information. SMEs were also found to lack experts in the human resource field. SME owners should invest and support more activities such as training, expanding human resource development policies, and develop appropriate training methods using the latest technology of mass media such as Facebook or Instagram based on the specific needs for SMEs [19].

Currently, SMEs have been exposed to the use of ICT in making business transactions to compete in highly competitive markets while gaining access at the global level. The importance of using e-businesses for the economic success and survival of SMEs has forced them to adapt to remain sustainable in the future. SMEs are now more likely to use ICT to improve data accuracy, speed up processes and reduce employees' blunders. The use of technology in financial matters has proven to spur the use of ICT among SMEs [12].

ICT can help SMEs in improving the standard of living. On the contrary, there are still SMEs who do not utilize online business transactions despite having an internet connection [85]. Thus, the role of this course is to encourage SMEs to use ICT in their daily business activities. ICT can help to improve business [11]. Nonetheless, SME owners should invest in relevant courses in training staff to manage the technology.

According to [5], training and taking courses in ICT can make the industry much mature in accordance with the relevant field. SME owners who provide formal courses have been proven to increase the level of readiness among their employees in accepting new technologies as well as creating skilled workers [78]. For example, the Kenyan government should support the training programs and widen the use of ICT among SMEs and they will see positive impacts on the country's development [45].

\section{Limitations Faced by SME Owners in Course Selection}

SME owners need to intensify their knowledge regularly [37]. They cannot afford to be left behind as the world is moving very fast, and they would incur losses if the way they do business is traditional [57]. There are various government initiatives to encourage SMEs to participate in courses and trainings to increase knowledge and skills. A study conducted by [68] shows that the support given by the government has resulted in a tremendous improvement in ICT skills amongst the SMEs. However, there are still many SMEs who have not yet had the opportunity to follow the courses provided. There are several factors that contribute to the limitations of SMEs in participating in the courses and training provided.

Among the factors are commitments such as family, children, and others. Thus, they are unable to find a suitable time to enhance their skills and knowledge of the business [70]. Additionally, time is also the main deterrent for them, preventing them to pursue the skills and knowledge that they need for their business. Therefore, for those who want to enforce or carry out short courses, they need to understand these constraints and find ways so that the courses that were developed can overcome these problems, and also are able to facilitate the affairs for both parties. Other than that, one of the major concerns shouldered upon the SME owners are the financial constraints [7] [70]. This is because with the present commitments, they are not ready for additional hardships. This is not the case for younger generations, as they have more opportunities and financial assistance for their learning level. Most SME operators are unaware of the existence of free courses provided by the government. This is due to the inadequate disclosure about the courses offered for them. They assume that the courses offered for them cover supplementary knowledge related to ICT, and that they are incapable to participate because they think it will incur a high cost. 
In order to enhance knowledge, SMEs are urged to continuously provide mental and physical support to their employees. This is because a consistent support system from family, friends and employers will poise their spirit and diligence to seek knowledge. There is a positive opportunity for employees to complete course sessions if they get support from their employers [21]. In ensuring them to stay focused and motivated while engaging in a course, it is important for them to know the purpose and outcome of them attending the course [20]. This is needed to make them feel confident with their learning process.

\section{Thematic Analysis (TA)}

Thematic Analysis developed by [17] which have later been applied in various fields of study. According to them, TA is a process of identifying patterns or themes in qualitative data. The goal of TA is to identify themes and patterns in important data and use these themes to articulate an issue in research. This method will not only summarize the data but will also interpret and understand the data better. The interview method has been identified as the main method in finding the theme.

TA is a qualitative method that can be learned easily because it has complete methods and procedures [17]. TA is also described as flexible theory and meaningful knowledge [18], therefore, researchers should perform a structured procedure in controlling data thus producing reliable reports. This clearly proves that this method provides unique flexibility in accordance with the research questions and data forms developed by the researchers. This analysis takes into account the experiences, perspectives, practices and behaviors of the respondents through direct interaction. Qualitative research should show that the analysis that has been conducted is reliable, accurate, consistent, and covers the whole subject through recording, systematic in nature, with complete details to prove that a method such as TA is reliable to use [53]. An article wrote by [62] implemented TA as a method to identify factors affecting SME owners in adopting ICT in business and found reliable reasons that can contribute to other research. For the number of respondents, four is the minimum number of respondents coming from various backgrounds to get a clear picture of the problems encountered [42]. There are six phases developed by [17]. Table I shows the phases and descriptions of TA method.

For the first phase, the first step in qualitative analysis by [17] is for the researchers to familiarize themselves with the data by reading, repeating and understanding the entire data and transcripts. As for the second phase which is to generate the initial code, [17] suggested that researchers should manage the data in a more systematic way by encoding each relevant data segment on research study questions and used open code when it does not have pre-code-set, and should also grow and modify the code as it does through the coding process. After that, the researcher needs to discuss and develop some introductory ideas about the code. Then the transcript code assignment is done separately. Transcript encoding is performed on each relevant text segment to address the research question. After that, the code is compared and discussed before moving on to another transcript. Researchers have the option to create manually through printed transcripts or by using qualitative data analytics software such as ATLAS.ti and Nvivo [34] which are suitable for large data sets. In addition, Microsoft Excel can also be used as an option in identifying themes.

For the third phase of finding the theme, [17] identified that the theme is a pattern that captures something important about the data from the research questions. If the data set is small, there may be similar data between the encoding level and the initial theme identification level. In this case the researcher studies the codes that eventually become the theme. At the end of this step, the code has been organized into a broader and more specific theme of the research question. This theme is descriptive and illustrates patterns in data related to research questions. This fourth phase as the theme review phase, where researchers need to study, modify, and develop the introductory theme already known in Phase 3 [17]. At this point, all data related to each theme is collected and classified according to colors. The next step is to relate with the function of the theme in an interview. The themes should be clear, and they should be different from the others. This is the final stage of the theme which is developed by [17], where the fifth phase is the determination phase, used to identify the essence of the theme. Themes need to be discussed, to know if there are subthemes, how they interact and relate to the main theme and how the themes relate to one another. In this analysis, feedback is a holistic theme rooted in other themes. Lastly, the results of this study from TA should be recorded in the form of a report.

\section{E. Expert Panel Judgement}

In the development of a model or the use of modified research instruments, a panel of experts can be involved as individuals who can provide feedback on the importance, appropriateness, and accuracy of the content, as well as clarity of meaning of each item in the research instrument [6]. There are three steps in the instrument validation staged by the panel of experts, namely, pilot study, reliability, validity analysis and item improvement [8]. The panel of experts is selected from a population of experienced researchers and industry players from various fields in entrepreneurship and language. Definition of panel of experts in the context of this study as people who have published journals in their respective fields or have experience working in the field for several years and hold important positions in an organization [14]. According to the study, the appropriate number of expert panels for each study depends on the research's needs. There are studies that use the services of three expert panels [29], and five expert panels [3] [9] [80].

TABLE I. Phases OF THEMATIC ANALYSIS By [17]

\begin{tabular}{|l|l|}
\hline Phase & Description \\
\hline $\mathbf{1}$ & Familiarizing yourself with the data \\
\hline $\mathbf{2}$ & Generating initial codes \\
\hline $\mathbf{3}$ & Searching for themes \\
\hline $\mathbf{4}$ & Reviewing potential themes \\
\hline $\mathbf{5}$ & Defining themes \\
\hline $\mathbf{6}$ & Producing the report \\
\hline
\end{tabular}




\section{MethodOLOGY}

\section{A. Objectives and Aims}

The methodology used in this study is divided into two main phases, namely, the data collection phase and the conceptual development phase of the qualitative study. These two main phases have their own methods, but the output from the first phase is the input for the second phase. The first phase is the data collection phase using the Thematic Analysis method. The second phase is the development phase of the smart entrepreneurship training framework for the use of SMEs in Malaysia. The purpose of this study is to identify courses that are relevant for SMEs in Malaysia. The target groups in this study are SME owners who own businesses in Kuala Lumpur and Selangor.

\section{B. Thematic Analysis Method}

The first phase conducted in this study is the data collection process. This study was conducted through the method of interviewing a total of eight SME owners and analyzing them using the TA method developed by [17]. This is the method to identify and analyze the meaning patterns in data sets, and to describe the themes that are the most important in a conducted study. TA method is suitable to identify the objectives for this study. Furthermore, this process begins when researchers are able to identify potential issues while collecting the data [17].

\section{Intruments}

The method used for this study was interview. Interviews are used to gather information ranging from how to select the appropriate courses and the type of courses, to the performance changes shown after attending the course. The first part of the interview begins with the consent notice requesting that each respondent express their consent to record the interview using a Sony ICD-UX543F digital voice recorder. Next, demographic questions are provided in the second part of the interview form to get more information about the participants and businesses. The third part of the form presents objective of the study along with the questions used by the researcher, to each respondent. The questions are used as the basis of the interview and the researcher reserves the right to add to the other questions depending on the answers given by the respondents. This is to get the actual reactions and reality faced by the respondents in sharing information about the course and the impact after attending the course.

After recording the data from the respondents, the researchers transcribed the data into word form and used Microsoft Excel to store the data. Survey data were then analyzed using the Thematic Analysis method. The list of interview questions is as follows:

1) Do you know about the courses?

2) Is there a need for employees to attend courses?

3) List the courses that you or the staff has attended?

4) How often do you send employees to attend courses?

5) Which section needs the most courses?

6) How do companies / employees find suitable courses?

7) Is the employer or employee deciding to attend the course?
8) Does the company provide financial assistance for the use of the course?

9) What is your opinion on the duration of the course?

10)How to identify the appropriate time for employees to be sent for courses?

11)How are the changes shown by the employees after attending the course?

12)What changes are seen in the employees after attending the course?

13)Is there a connection between the course and the performance of employees?

14)What is your response to the course you have attended?

15)Can you share what you want in a course?

\section{Respondents}

A total of eight SME owners had agreed to be the respondents for this study. All respondents were selected randomly after identifying their business background. The respondents consisted of 2 males (33.3\%) and 6 females (66.7\%). The age of the respondents selected was between 32 and 57 (Average: 42.625; Standard Deviation: 7.652). The type of businesses of the respondents was based on products (33.33\%) and on services (66.67\%). All respondents had been in business for 4 to 21 years. 75\% of the respondents had been in business from 1 to 10 years, 12.5\% from 11 to 20 years, and $12.5 \%$ from 21 to 30 years. Table II shows the details of the respondents' background. The eight respondents came from various business backgrounds. Their age ranged from 32 to 57 years, and the year of establishment was from 1999 to 2016. All eight respondents had attended business courses throughout their business.

TABLE II. DETAILS OF EIGHT (8) RESPONDENTS FOR INTERVIEW SESSIONS

\begin{tabular}{|l|l|l|l|l|}
\hline R & Gender & $\begin{array}{l}\text { Establishment } \\
\text { Year }\end{array}$ & $\begin{array}{l}\text { Product / } \\
\text { Service }\end{array}$ & Type of Business \\
\hline R1 & Female & 2016 & Product & Cosmetic \\
\hline R2 & Female & 2013 & Service & Tailor \\
\hline R3 & Male & 1999 & Product & Halal Meats \\
\hline R4 & Female & 2016 & Product & Bakery \\
\hline R5 & Female & 2006 & Service & Tailor \\
\hline R6 & Male & 2010 & Service & Medical Supplies \\
\hline R7 & Female & 2014 & Product & $\begin{array}{l}\text { Printing and } \\
\text { Souvenirs }\end{array}$ \\
\hline R8 & Female & 2016 & Service & Tailor \\
\hline
\end{tabular}

\section{E. Procedure}

As mentioned before, this study was conducted through interviews. The respondents required to complete this study are the SME owners who have been conducting business activities for more than four years by selling products or offering services. The selection of respondents is random, and business is conducted around Kuala Lumpur and Selangor, Malaysia. Researchers had contacted respondents and set a time to meet. After meeting at the promised place and time, the researcher explained about the study to be conducted and followed by an agreement form to record the interview. Respondents were 
asked to sign a consent form for the interview to be recorded and asked to fill in personal and business information in the second part of the form. In the third part of the consent form, the researcher had listed three (3) study objectives and questions used for the study. During the interview, the researcher used the question and occasionally added questions depending on the answers and information shared by the respondents. As a token of appreciation, the researchers presented souvenirs from the Famous Amos shop at the end of the interview session. The same process was repeated until the eighth respondent.

Phase 1: Thematic Analysis:

After the interview session, the researchers collected all the audio data and uploaded the file to a laptop and created a set of storage files for security purposes. All twelve audio data files were then transcribed into words using Excel software. The Excel data was then printed and repeated reading was done to understand the details of the interview.

Based on the set of questions asked during the interview session, the researchers tried to get the starting code based on the answers given by the respondents. Researchers reduced the data to be more focused on important data. After creating almost nine types of code and classifying using pencil colors, the process then moved on to the next transcript.

After identifying the starting code, the researcher performed the third phase which is to find the theme by collecting the codes which then formed the same set of data sets for each transcript.

After finding the theme, the researcher reviewed, modified, and developed the initial theme and reviewed the theme to ensure it coincides with the objectives of this study. The data was then reviewed repeatedly and only data that felt like it was important was stored. The theme should be clear with the objectives of the study and should be found in all twelve of the transcripts.

The researcher then analyzed and determined the theme and found sub-themes where this data interacts and relates between the main themes in the data set. After obtaining the code, themes and sub-themes, the researcher then formed a model framework based on the findings from the study. A report is produced which includes the objectives of the study, literature review, research methods, analysis, results, and a thorough discussion of this study.

Phase 2: Expert Panel for Course Selection Concept Framework

The involvement of a panel of experts is aimed at obtaining their confirmation of the accuracy of the concept framework of suitable course selection for SMEs presented by the researchers. It refers to the basic knowledge that SME owners need to know in managing an organization. All instruments and items identified were brought to a group of experts to check their accuracy according to the purpose of the study. To this end, researchers have met with four experts in the areas of organizational management, marketing and digital marketing, accounting, operations, and Language. In the meeting, the researchers demonstrated the smart entrepreneurship training framework developed using the TA method. The concept was then accompanied by 55 items based on the theme namely business management, sales and marketing, accounting and finance, information technology and operations and production. The combination of these four experts consisting of academics and business consultants aims to get a more comprehensive view of the SME course selection concept framework. These experts not only look at the theoretical aspects, but also look at the practical aspects that can be applied and will have an impact on SME entrepreneurs in Malaysia. Table III shows the background of the U-PPM system expert panels according to expertise [1].

TABLE III. BACKGROUND OF THE EXPERT PANEL

\begin{tabular}{|c|c|}
\hline Panel Experts & Work Experiences \\
\hline $\begin{array}{l}\text { Panel Expert } 1 \\
\text { Educational Leadership and } \\
\text { Language Expert }\end{array}$ & $\begin{array}{l}\text { 1. Associate Professor } \\
\text { Universiti Teknologi Malaysia } \\
(1989-\text { Current) } \\
\text { 2. Director General } \\
\text { Dept. of Community College } \\
(2009-2011)\end{array}$ \\
\hline $\begin{array}{l}\text { Panel Expert } 2 \\
\text { Marketing and Entrepreneur } \\
\text { Development Expert }\end{array}$ & 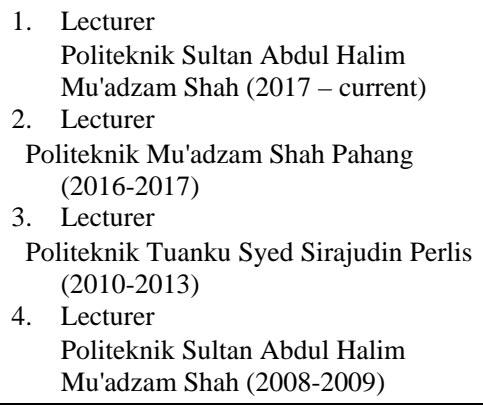 \\
\hline $\begin{array}{l}\text { Panel Expert } 3 \\
\text { Business Management, Logistic } \\
\text { and Operation Expert }\end{array}$ & $\begin{array}{ll}1 . & \text { Director Technoputra Division } \\
\text { Universiti Kuala Lumpur } \\
\text { (2019 - Current) } \\
\text { 2. } & \text { General Manager } \\
\text { UniKL Resources Sdn.Bhd } \\
\text { (2014 - 2018) } \\
\text { 3. Senior Lecturer } \\
\text { UniKL Malaysian Institute of } \\
\text { Industrial Technology } \\
(2009-2014)\end{array}$ \\
\hline $\begin{array}{l}\text { Panel Expert } 4 \\
\text { Accounting and Digital } \\
\text { Marketing Consultant Expert }\end{array}$ & $\begin{array}{ll}\text { 1. } & \text { Founder \& Director } \\
\text { UpRiser Success Terminal } \\
\text { 2. } \\
\text { Director of Training Management } \\
\text { JNJ Management Consultants }\end{array}$ \\
\hline
\end{tabular}

\section{RESULTS}

\section{A. Phase 1: Thematic Analysis}

As indicated earlier, the TA method was used in this study to identify the list of relevant courses for the SMEs. The results of this method will be used as an input for the development of a smart entrepreneurship training framework for SMEs. This study has found a list of courses attended by entrepreneurs, and it has been divided into five basic divisions in an organization. The divisions are in the areas of business management, sales and marketing, accounting and finance, ICT and technology and production and operations. Table IV is an analysis using the TA Method to identify the theme. It is arranged with the prefix code obtained by the researcher according to the same set of answers given by the respondents. 
TABLE IV. THEMES, SUB-THEMES AND CODES FOR THE LIST OF COURSES ATTENDED

\begin{tabular}{|c|c|c|c|}
\hline Theme & Sub-Theme & Code & Respondents \\
\hline \multirow{3}{*}{$\begin{array}{l}\text { Manage- } \\
\text { ment }\end{array}$} & $\begin{array}{l}\text { Management } \\
\text { Strategy }\end{array}$ & $\begin{array}{l}\text { Find ways to plan } \\
\text { strategies for business } \\
\text { fundamental, } \\
\text { management and } \\
\text { communication }\end{array}$ & $\begin{array}{l}\text { R2, R4, R5, } \\
\text { R8 }\end{array}$ \\
\hline & $\begin{array}{l}\text { Leadership } \\
\text { Skills }\end{array}$ & $\begin{array}{l}\text { Find the internal skills } \\
\text { you need to have as an } \\
\text { owner }\end{array}$ & R7 \\
\hline & $\begin{array}{l}\text { Human } \\
\text { Resource } \\
\text { Management }\end{array}$ & $\begin{array}{l}\text { Courses on managing } \\
\text { Human Resource }\end{array}$ & $\mathrm{R} 1$ \\
\hline $\begin{array}{l}\text { Sales \& } \\
\text { Marketing }\end{array}$ & $\begin{array}{l}\text { 4P's } \\
\text { (Place, Price, } \\
\text { Promotion, } \\
\text { Product) }\end{array}$ & $\begin{array}{l}\text { Courses on digital } \\
\text { marketing, Marketplace }\end{array}$ & $\begin{array}{l}\text { R1, R2, R4, } \\
\text { R5, R7, R8 }\end{array}$ \\
\hline \multirow{3}{*}{$\begin{array}{l}\text { Account \& } \\
\text { Finance }\end{array}$} & Cash Flow & $\begin{array}{l}\text { Courses on accounts } \\
\text { and finance }\end{array}$ & $\begin{array}{l}\text { R1, R2, R4, } \\
\text { R7, R8 }\end{array}$ \\
\hline & Tax & Courses on tax & R3 \\
\hline & $\begin{array}{l}\text { Asset } \\
\text { Management }\end{array}$ & $\begin{array}{l}\text { Courses on managing } \\
\text { company assets }\end{array}$ & R5 \\
\hline \multirow{2}{*}{$\begin{array}{l}\text { ICT \& } \\
\text { Technology }\end{array}$} & Infrastructure & $\begin{array}{l}\text { Courses on technical } \\
\text { and computer }\end{array}$ & R2, R6 \\
\hline & $\begin{array}{l}\text { Digital } \\
\text { Platform }\end{array}$ & $\begin{array}{l}\text { Courses on apps and } \\
\text { internet }\end{array}$ & R2, R7 \\
\hline $\begin{array}{l}\text { Production } \\
\text { \& Operation }\end{array}$ & $\begin{array}{l}\text { Standard } \\
\text { Operating } \\
\text { Procedure }\end{array}$ & $\begin{array}{l}\text { Courses based on } \\
\text { organization's need }\end{array}$ & R3, R5 \\
\hline
\end{tabular}

Researchers identify that through the code of business planning strategy, business basics, and communication; it coincides with the sub-theme of management strategy and is directly within the business management theme. Four respondents have said that they have attended courses related to this topic to gain knowledge and understanding for the purpose of improving their business. Two of the narratives are as follows:

"Motivation classes, apps and knowledge about accounts been thought in the second week. Other than that, communication course and the techniques depend on each field." - R2.

"When I started my business, I took a basic business course from MARA. Then, I joined Baitulmal Entrepreneur Program, and they gave more entrepreneur courses." - R8.

For the code under internal skills, the sub-themes are leadership skills and management. The narratives from the respondents are as follows:

"Dr Azizan's course - Marketing and internal strength as an owner. He taught us how we have to handle a company, how we want to drive. What is the future holds? Mastering Marketing, Zero Marketing, Account. We went to all courses." - R7.

Still under the theme of Management with the sub-theme of Human Resource Management, the initial code achieved is to find a course on human resources and its narrative, which is as follows:
"I have attended the Hasbul Brothers course for Management. We have to take care of everything including cash flow, handle customer rejection and HR to take care of staff." - R1.

Under the theme of Sales and Marketing, the sub-themes listed include four 'Ps', namely, Place, Price, Promotion, and Product. The pre-code leads to the need of finding the courses related to marketing, digital marketing, and online platforms. Examples of narratives are as follows:

"Entrepreneurship courses, pre-business courses, Marketing courses." - R5.

"We went to Dr. Azizan's courses because it is more to Marketing." - R7.

"It is an online marketing now. Hence, we can't wait for customers at the store. So, we have to do something for example to search for suitable platform to go online." -R8.

For the accounting and finance theme, the first sub-theme is Cash Flow, and the initial code is looking for financial and account management courses. The narratives are as follows:

"Now, after attending the course, we knew that the cash flow has to be recorded and saved. Before this, the money was spent just like that. Hence, we managed to get the Management awareness which is an impact after attending the course." - R8.

"Motivation classes, apps and knowledge about accounts been thought in the second week. - R2.

"I went to Entrepreneurship course, ways to manage a business, managing financial data and our business channel and digital marketing." - R4.

Next, in the theme of accounting and finance, the subtheme is taxation, where the code is a course on taxation. The narrative is as follows:

"It's all like Tax. You see, I'm good at talking, I can approach, but in terms of management, I am not good at that. The staff who went for the course had to handle everything (tax)." - R3.

Still under the theme of accounting and finance, the important course is to start with the initial code of managing the company's assets and lead to the sub-theme of asset management, the respondents' narrative is as follows:

"There are also financial and asset management courses for companies. That is important." - R5.

Under the theme of ICT and technology, the courses are considered important by the respondents. Under the infrastructure sub-theme, the initial codes are technical, and computer related. The narrative is as follows: R2.

"Sometimes, we have to know the ICT and computers." -

Furthermore, still under the theme of ICT and technology, the initial codes found are of applications and the internet. Both are under the sub-themes of digital platforms. The narrative is as follows: 
"I went through a course at Taylor's University to learn about promoting our own products. I learnt to download the apps to beautify those pictures and the importance of WhatsApp Business." - R2.

"Irfan Khairi is more to Technical. He taught on the technical part on how to upload something through the Internet. It was in 2010 and the internet did not go very well back then."- R7.

Under the initial code of requirements of a particular organizational field, it leads to the sub-theme of Standard Operating Procedures (SOP), which is under the theme of production and operation. The respondents' narrative is as follows:

"It is a course for Halal to cut chicken and beef so this course is a must for hygiene." - R3.

"I am in the field of sewing. In 1994, I studied the course for full-time for a year." - R5.

Researchers have developed a smart entrepreneurship training conceptual framework using the results of the study using the TA method. Fig. 1 shows a complete chart on the selection of courses that are important for the needs of SME organizations doing businesses in Malaysia.

\section{B. Phase 2: Findings from Expert Panel's Feedback}

Following the development of a smart entrepreneurship training conceptual framework, a website was developed to help SME owners to make the right course selection for their organization. This is important because, there are various selections of courses available in the market; hence the SME owners have to make the right decision in choosing the courses that offer knowledge and experience which will then be beneficial for their business.

Researchers have developed the items based on the result of the analysis and the course selection concept framework development. Next, the development of the items and instruments needs to get an approval from the experts in the various fields. Hence, a group of experts in the related fields have conducted a research and validated the items and instrument used in the system known as the Malaysian SMEs Psychometric Test or U-PPM. This activity is done to examine the accuracy of items and instrument developed by researchers, to determine the courses chosen by SMEs to meet the needs of their organizations. Prior to the development of this U-PPM, a study was conducted based on in-depth interviews with eight SME owners. Researchers have analysed the results of the interviews using TA method and have produced an instrument that has five themes along with fifty-five items.

For that purpose, each expert has been asked to validate each theme and item. After reviewing all the items, the experts are required to fill out a form as an evidence of their agreement and feedback. Feedback obtained from all experts leads to the removal, addition, modification, and positioning of items. The development of this holistic and practical U-PPM system is expected to contribute to the field of theory and practice that benefits SMEs, especially to the training providers in Malaysia. Table V shows the results by the four experts. Items have been reduced to 50 from 55 .

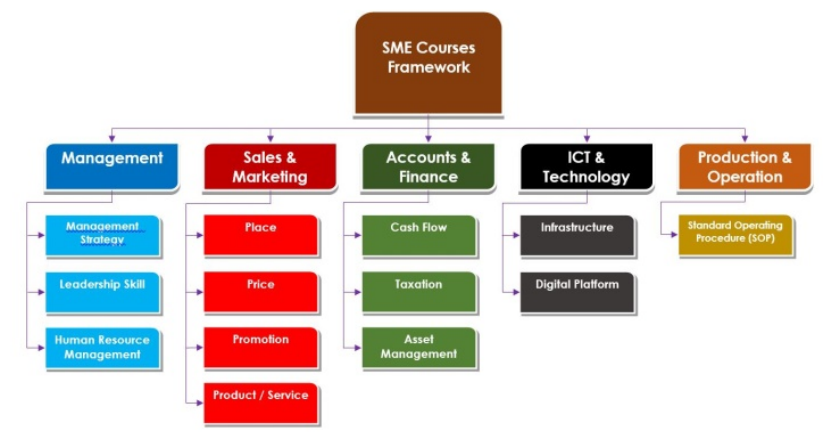

Fig. 1. SME’s Smart Entrepreneurship Training Framework Components.

TABLE V. EXPERT PANEL (EP) RESULTS FOR U-PPM ITEMS

\begin{tabular}{|c|l|l|l|l|l|l|}
\hline No & Details & EP 1 & EP 2 & EP 3 & EP 4 & $\%$ \\
\hline 1. & $\begin{array}{l}\text { The format of the study } \\
\text { instrument is appropriate } \\
\text { and interesting }\end{array}$ & Agree & Agree & Agree & Agree & 100 \\
\hline 2. & $\begin{array}{l}\text { The meaning of each item } \\
\text { is clear }\end{array}$ & Agree & Agree & Agree & Agree & 100 \\
\hline 3. & $\begin{array}{l}\text { The language used is easy } \\
\text { to understand }\end{array}$ & Agree & Agree & Agree & Agree & 100 \\
\hline 4. & $\begin{array}{l}\text { The instructions given are } \\
\text { clear }\end{array}$ & Agree & Agree & Agree & Agree & 100 \\
\hline 5. & $\begin{array}{l}\text { The instructions for the } \\
\text { measurement scale are } \\
\text { clear }\end{array}$ & Agree & Agree & Agree & Agree & 100 \\
\hline 6. & $\begin{array}{l}\text { The objectives of the } \\
\text { instrument stated are clear }\end{array}$ & Agree & Agree & Agree & Agree & 100 \\
\hline 7. & $\begin{array}{l}\text { The number of items used } \\
\text { is appropriate }\end{array}$ & $\begin{array}{l}\text { Dis } \\
\text { agree }\end{array}$ & Agree & Agree & $\begin{array}{l}\text { Dis } \\
\text { agree }\end{array}$ & 50 \\
\hline & $\begin{array}{l}\text { The whole idea presented } \\
\text { interesting }\end{array}$ & Agree & Agree & Agree & Agree & 100 \\
\hline
\end{tabular}

\section{Discussion}

Based on the result from the researcher's interview with eight SME owners, there are five main components in the selection of business training courses for SMEs in Malaysia. The main themes are business management, sales and marketing, accounting and finance, ICT and technology, and production and operations. These themes show that most SMEs chose to deepen their knowledge in the related field towards the organization they are leading. Table VI lists the themes and sub-themes derived from the TA method.

As for Business Management theme, the sub-themes resulting from the findings of this study are business management strategies, leadership skills, and human resource management. According to a study conducted by [52], SMEs can upgrade the entrepreneurial skills among them by acquiring lofty knowledge and management capabilities. This includes competency in distributing the tasks in the business, followed by assessing skills, and proficiency in human resource management. This finding is supported by [55] who says that human resource management is one branch of economics that is closely related to the success of an organization and business. For that, SME owners are encouraged to attend management and leadership skills courses 
to boost their internal and peripheral capabilities in order to maintain sustainability and success in developing the enterprises [79].

As for the sales and marketing theme, an important subtheme in marketing development is the application of mixed marketing elements, which are also known as 4P's, namely, place, price, promotion, and product. This mixed marketing framework plays an important role in strengthening the brand of SME products nationwide [66] other than influencing consumer purchasing decisions [64]. SMEs are found to be accomplished in conducting market research and defining the criteria and advantages of the products to customers and are capable in determining the rivalry strengths and weaknesses as well as to boost organisational monthly profits [52]. Apart from that, SMEs should engage in courses that apply knowledge related to ICT in order to enhance the way they do marketing and promotion of the products [84].

On the other hand, for accounting and finance codes in TA, the theme arising was involved with the knowledge of cash flow, taxation, and asset management. A study on financial management practices on MADA entrepreneurs conducted by [81] shows that those with a moderate level of financial experience were unable to manage their own finances without the need of help from others. Scores on financial knowledge, skills, attitudes, and financial planning are in the rank because they followed programs organized by their top management in acquiring the knowledge on financial management. Some of the entrepreneurs did not practice the system in documenting their transactions in the ledger, thus making the course on cash flow and taxation an important element in accounting and financial management [81].) Investigation on KADA entrepreneurs shows that their financial management is at a bearable level [67]. This is because, they have less experience. Therefore, KADA entrepreneurs are encouraged to participate in courses to improve financial knowledge and smoothen their business progress.

TABLE VI. THEMES AND SUB-THEMES FOR TA METHOD

\begin{tabular}{|l|l|}
\hline \multirow{5}{*}{ Theme } & Sub-theme \\
\hline \multirow{5}{*}{ Sanagement } & Management Strategy \\
\cline { 2 - 2 } & Leadership Skills \\
\cline { 2 - 2 } & Human Resource Management \\
\hline \multirow{5}{*}{ Accounts \& Finance } & Place \\
\cline { 2 - 2 } & Price \\
\cline { 2 - 2 } & Promotion \\
\cline { 2 - 2 } & Product \\
\hline \multirow{5}{*}{ ICT \& Technology } & Cash Flow \\
\cline { 2 - 2 } & Taxation \\
\cline { 2 - 2 } & Asset Management \\
\hline Production and Operation & Infrastructure \\
\cline { 2 - 2 } & Digital Platform \\
\hline
\end{tabular}

For the ICT and technology theme, the sub-themes are related to the infrastructure provided by SME owners and the importance of digital platforms. ICT has a tremendous economic impact on entrepreneurs if they have benefited to the fullest on the effective use of technology in advancing their businesses. However, their monthly income also affects the status of computer ownership among SMEs [61]. For SME participation in the digital field, a study by [54] said that digital participation is important for the advancement of their business and the source of information related to the latest products in the market. Entrepreneurs no longer need to face customers or have a one-way communication, because they have switched to streamline sales. Therefore, the application of knowledge on ICT needs to be further strengthened to bring these SMEs to a greater height. A study conducted by [60] showed that the factors of digital literacy, customer relationship building, and digital ecosystem building play an important role in influencing the use of digital platforms by SMEs. He added that these findings are a useful guide to stakeholders in designing educational programs related to the use of digital platforms for SME entrepreneurs.

For the production and operational theme, the sub-themes involved are related to the Standard Operating Procedures (SOPs) in an organization. According to [82], informal learning and previous experience have given lots of input to SMEs in managing their businesses. Therefore, SMEs need to acquire knowledge related to the management and products operation and services, because this would provide a positive impact in their business, will help in boosting their income, and hence help them remain competitive.

\section{CONCLUSION}

This survey was conducted to develop a comprehensive course selection system for SMEs. The reason being, selecting an appropriate course could influence the performance of the SMEs other than to enhance profits for the organization. The development of this model uses two qualitative methods, which are, Thematic Analysis and Expert Panels. Through this study, the researcher found that there are five important business education courses needed by the organizations. The themes are business management, sales and marketing, accounting and finance, ICT and technology, and production and operations. For the management theme, there are three sub-themes, namely, management strategy, leadership skills, and human resource management. For the sales and marketing theme, subthemes are mixed with marketing, which follows the 4Ps, namely, place, price, promotion, and product. The three subthemes for the accounting and finance theme are cash flow, taxation, and asset management. The two sub-themes to the ICT and technology theme are infrastructure and digital platform. Finally, the sub-theme for production and operations is the Standard Operating Procedures in accordance with the needs of the respective organizational area of expertise.

These findings are useful for SME owners and the top management, who would be able to ensure that efforts and actions are taken in order to fully utilize the usage of an ICT in their business operation, and that the sustainability of their 
organization would be maintained. As a result of the Thematic Analysis method, researchers have developed a smart entrepreneurship training framework of courses selection system for SMEs that has led to the development of items and instrument for a website known as the Malaysian SMEs Psychometric Test or U-PPM. Four expert panels from the areas of organizational management, marketing and digital marketing, accounting, and operations and language have agreed to carry out their responsibilities to validate the items used in the development of this U-PPM system for the next agenda of the study. It is hoped that with the existence of this U-PPM, SME owners can make the right decision in identifying the needs for acquiring business knowledge in entrepreneurship courses.

\section{REFERENCES}

[1] Abd. Ghani, Basri and Adnan, Ahmad Azrin (2017) Penilaian pakar dalam model konseptual penggunaan berhierarki Islam / Basri Abd. Ghani and Ahmad Azrin Adnan. In: 2nd International Islamic Heritage Conference (ISHEC 2017).

[2] Aca, L. A. O. (2018). Owner Financial Literacy Charateristic: Implication for Access to Finance Among Smes in Kwara State Nigeria. Fountain University Osogbo Journal of Management, 3(1).

[3] Adnan, A. A. (2017). Penilaian pakar dalam model konseptual penggunaan berhierarki Islam/Basri Abd. Ghani and Ahmad Azrin Adnan.

[4] Al-Awlaqi, M. A., Aamer, A. M., \& Habtoor, N. (2018). The effect of entrepreneurship training on entrepreneurial orientation: Evidence from a regression discontinuity design on micro-sized businesses. The International Journal of Management Education, 100267.

[5] Albors-Garrigós, J., Hervas-Oliver, J. L., \& Márquez, P. (2009). Internet and mature industries. Its role in the creation of value in the supply chain. The case of tile ceramic manufacturers and distributors in Spain. International Journal of Information Management, 29(6), 476-482.

[6] Ali, R., \& Buang, N. A. (2018). Kompetensi Keusahawanan Sebagai Mediator Kesediaan Penerapan Elemen Keusahawanan dalam Kalangan Pensyarah Institut Pendidikan Guru (IPG) (Entrepreneurship Competency as a Readiness Mediator in the Implementation of Entrepreneurship Elements Among Lecturers of Teacher Institute). Jurnal Pendidikan Malaysia (Malaysian Journal of Education), 43(1SI), 123-130.

[7] Antonioli, D., \& Della Torre, E. (2016). Innovation adoption and training activities in SMEs. The International Journal of Human Resource Management, 27(3), 311-337.

[8] Ariffin, S. R., Ahmad, J., \& Najmuddin, N. A. (2010). The Developing Students Generic Skills Instrument Through Lecture Assessment Based on Many-Facets Rasch Measurement Model. Jurnal Pendidikan Malaysia (Malaysian Journal of Education), 35(2), 43-50.

[9] Asbulah, L. H., Lubis, M. A., \& Aladdin, A. (2018). Kesahan dan Kebolehpercayaan Instrumen Strategi Pembelajaran Kolokasi Bahasa Arab: Analisis Menggunakan Model Rasch (Validity and Realibility of Arabic Collocation Learning Strategies Instrument: Analysis Using Rasch Model). Jurnal Pendidikan Malaysia (Malaysian Journal of Education), 43(1SI), 131-140.

[10] Assaad, R., Krafft, C., \& Yassin, S. (2020). Job creation or labor absorption? An analysis of private sector job growth in Egypt. Middle East Development Journal, 1-31.

[11] Assante, D., Castro, M., Hamburg, I., \& Martin, S. (2016). The use of cloud computing in SMEs. Procedia computer science, 83, 1207-1212.

[12] Azmi, A., Sapiei, N. S., Mustapha, M. Z., \& Abdullah, M. (2016). SMEs' tax compliance costs and IT adoption: the case of a value-added tax. International Journal of Accounting Information Systems, 23, 1-13.

[13] Bayrakdaroğlu, A., \& Şan, F. B. (2014). Financial literacy training as a strategic management tool among small-medium sized businesses operating in Turkey. Procedia-Social and Behavioral Sciences, 150, 148155 .
[14] Beecham, S., Hall, T., Britton, C., Cottee, M., \& Rainer, A. (2005). Using an expert panel to validate a requirements process improvement model. Journal of Systems and Software, 76(3), 251-275.

[15] Bongomin, G. O. C., Ntayi, J. M., Munene, J. C., \& Malinga, C. A. (2017). The relationship between access to finance and growth of SMEs in developing economies. Review of International Business and Strategy.

[16] Bradford, S. K., Rutherford, B. N., \& Friend, S. B. (2017). The impact of training, mentoring and coaching on personal learning in the sales environment. International Journal of Evidence Based Coaching and Mentoring, 15(1), 133.

[17] Braun, V., \& Clarke, V. (2006). Using thematic analysis in psychology. Qualitative Research in Psychology, 3, 77-101.

[18] Braun, V., \& Clarke, V. (2019). Reflecting on reflexive thematic analysis. Qualitative Research in Sport, Exercise and Health, 11(4), 589597.

[19] Brien, E. O., \& Hamburg, I. (2014). Supporting Sustainable Strategies for SMEs through Training, Cooperation and Mentoring. Higher education studies, 4(2), 61-69.

[20] Byrne, J., Delmar, F., Fayolle, A., \& Lamine, W. (2016). Training corporate entrepreneurs: an action learning approach. Small Business Economics, 47(2), 479-506.

[21] Castaño Muñoz, J., Kalz, M., Kreijns, K., \& Punie, Y. (2016). Influence of employer support for professional development on MOOCs enrolment and completion: Results from a cross-course survey. Research Track, 251.

[22] Daud, S., Ahmad, S. N., \& Zohor, R. M. (2018). Kajian Tinjauan Keberkesanan Promosi Kursus Pendek di Kolej Komuniti Segamat 2. Politeknik \& Kolej Komuniti Journal of Life Long Learning, 2(1), 5064.

[23] Dubois, D., \& Rothwell, W. J. (2004). Competency-based or a traditional approach to training. T and D, 58(4).

[24] Dumitriu, D., Militaru, G., Deselnicu, D. C., Niculescu, A., \& Popescu, M. A. M. (2019). A perspective over modern SMES: managing brand equity, growth and sustainability through digital marketing tools and techniques. Sustainability, 11(7), 2111.

[25] Foroudi, P., Gupta, S., Nazarian, A., \& Duda, M. (2017). Digital technology and marketing management capability: achieving growth in SMEs. Qualitative Market Research: An International Journal.

[26] Frost, S. (2016). The importance of training \& development in the workplace. Small Business, http://smallbusiness. chron. com/importance-trainingdevelopment-workplace-10321. html.

[27] Garavan, T., Watson, S., Carbery, R., \& O’Brien, F. (2016). The antecedents of leadership development practices in SMEs: The influence of HRM strategy and practice. International Small Business Journal, 34(6), 870-890.

[28] Gielnik, M. M., Uy, M. A., Funken, R., \& Bischoff, K. M. (2017). Boosting and sustaining passion: A long-term perspective on the effects of entrepreneurship training. Journal of Business Venturing, 32(3), 334353.

[29] Harun, N., \& Ghani, F. A. (2016). Kesahan dan Kebolehpercayaan Soal Selidik Amalan Belajar Pelajar Berpencapaian Rendah Sekolah Berasrama Penuh. Jurnal Kemanusiaan, 14(3).

[30] Imran, M., \& Tanveer, A. (2015). Impact of training \& development on employees' performance in banks of pakistan. European journal of training and development studies, 3(1), 22-44.

[31] Jackson, G., \& Ahuja, V. (2016). Dawn of the digital age and the evolution of the marketing mix. Journal of Direct, Data and Digital Marketing Practice, 17(3), 170-186.

[32] Jain, T. K., \& Sharma, A. (2019). Impact of Training and development on Employee Performance in Retail Sector: A Review paper. Available at SSRN 3316856.

[33] James, J., Deacon, J., \& Huxtable-Thomas, L. (2016). Relationship marketing in high technology based SMEs: A customer perspective. In Let's Get Engaged! Crossing the Threshold of Marketing's Engagement Era (pp. 413-425). Springer, Cham. 
[34] Joffe, H. (2012). Thematic analysis. Qualitative research methods in mental health and psychotherapy, 1.

[35] Karim, M. M., Choudhury, M. M., \& Latif, W. B. (2019). The impact of training and development on employees Performance: An analysis of quantitative data. Noble International Journal of Business and Management Research, 3(2), 25-33.

[36] Katz, J. A., Hanke, R., Maidment, F., Weaver, K. M., \& Alpi, S. (2016). Proposal for two model undergraduate curricula in entrepreneurship. International Entrepreneurship and Management Journal, 12(2), 487506.

[37] Kim, N., \& Shim, C. (2018). Social capital, knowledge sharing and innovation of small-and medium-sized enterprises in a tourism cluster. International Journal of Contemporary Hospitality Management.

[38] Kirby, D. A. (2004). Entrepreneurship education: can business schools meet the challenge? Education+ training.

[39] Krishnan, T. N., \& Scullion, H. (2017). Talent management and dynamic view of talent in small and medium enterprises. Human Resource Management Review, 27(3), 431-441.

[40] Mabhungu, I., \& Van Der Poll, B. (2017). A review of critical success factors which drives the performance of micro, small and medium enterprises.

[41] Manresa, A., Bikfalvi, A., \& Simon, A. (2019). The impact of training and development practices on innovation and financial performance. Industrial and Commercial Training.

[42] Maree, J. G. (2015). Career construction counseling: A thematic analysis of outcomes for four clients. Journal of Vocational Behavior, 86, 1-9.

[43] Milner, J., McCarthy, G., \& Milner, T. (2018). Training for the coaching leader: how organizations can support managers. Journal of Management Development.

[44] Mohd Aris, N., Abas, S. A., Mohd Adnan, S. D., Md Nasir, M. F., \& Jalani, H. (2018). Modul usahawan tani Islam. e-Journal of Islamic Thought and Understanding (e-JITU), 1(1), 16-32.

[45] Mokaya, S. O., \& Njuguna, E. W. (2017). Adoption and use of information and communication technology (ICT) by small enterprises in Thika Town, Kenya.

[46] Mullins, R., Duan, Y., Hamblin, D., Burrell, P., Jin, H., Jerzy, G., ... \& Aleksander, B. (2007). A Web Based Intelligent Training System for SMEs. Electronic Journal of E-learning, 5(1), 39-48.

[47] Mungai, B. (2012). The relationship between business management training and small and medium-sized enterprises' growth in Kenya. Unpublished $\mathrm{PhD}$ Thesis, Kenyatta University.

[48] Musa, H., \& Chinniah, M. (2016). Malaysian SMEs development: future and challenges on going green. Procedia-Social and Behavioral Sciences, 224(2016), 254-62.

[49] Mustapha, Z., Ahmad, A. H., Kob, C. G. C., \& Zairon, I. Y. (2017). Peranan Kolej Komuniti Sebagai Pembimbing Dalam Memantapkan Niat Keusahawanan Pelajar. Politeknik \& Kolej Komuniti Journal of Social Sciences and Humanities, 2(1), 209-216.

[50] Nguyen, T. V., \& Bryant, S. E. (2004). A study of the formality of human resource management practices in small and medium-size enterprises in Vietnam. International small business journal, 22(6), 595618.

[51] Noor, N. M. (2015). Pengukuran personaliti keusahawanan dan prestasi perniagaan bahan binaan di Negeri Kelantan (Doctoral dissertation, Universiti Malaysia Kelantan).

[52] Noorzeli, N. M., \& Wahab, M. N. A. (2017). Keupayaan Usahawan Kecil Melaksanakan Kemahiran Keusahawanan Menggunakan Kaedah HRV Biofeedback. Malaysian Journal of Social Sciences and Humanities (MJSSH), 2(1), 65-76. (Semua Perbincangan).

[53] Nowell, L. S., Norris, J. M., White, D. E., \& Moules, N. J. (2017). Thematic analysis: Striving to meet the trustworthiness criteria. International Journal of Qualitative Methods, 16(1), 1609406917733847.

[54] Omar, F. I., Rahim, S. A., \& Dimyati, H. A. (2019). Analisis Pola Penyertaan Digital ICT dan Transformasi Keusahawanan. Jurnal Komunikasi: Malaysian Journal of Communication, 35(2).
[55] P Rameli, M. F., Sharif, D., \& Che Man, N. (2017). Etika pengurusan sumber manusia bagi Muslimpreneurs dalam perniagaan berskala kecil/Mohd Faizal P. Rameli.

[56] Pavlovic, S., Olukuru, J., \& Coelho, J. (2019). Impact of Training on Small and Growing Businesses. Available at SSRN 3472940.

[57] Penglin, L., \& Honghao, L. (2017). The New Thinking of the SMEs Transformation and Upgrading in Shaanxi Province: from the Internet Finance Perspective.

[58] Premand, P., Brodmann, S., Almeida, R., Grun, R., \& Barouni, M. (2016). Entrepreneurship education and entry into self-employment among university graduates. World Development, 77, 311-327.

[59] Ptak-Chmielewska, A., \& Matuszyk, A. (2018). The importance of financial and non-financial ratios in SMEs bankruptcy prediction. Bank i Kredyt, 49, 45-62.

[60] Ramdan, M. R., Abdullah, N. L., Isa, R. M., \& Hanafiah, M. H. (2020). Meneroka Faktor-faktor yang Mempengaruhi Penggunaan Platform Digital oleh Perusahaan Mikro dan Kecil. Jurnal Pengurusan (UKM Journal of Management), 59.

[61] Rashid, S. M. R. A. (2016). Keupayaan ICT dalam meningkatkan pencapaian usahawan wanita: Satu kajian kes usahawan luar bandar di Malaysia. e-BANGI, 11(2), 78-103.

[62] Rozmi A.N.A, Nohuddin P.N.E, Hadi A.R.A, Bakar M.I.A and Nordin A.I, "Factors Affecting SME Owners in Adopting ICT in Business using Thematic Analysis" International Journal of Advanced Computer Science and Applications (IJACSA), 11(7), 2020.

[63] Saad, M., Kumar, V., \& Bradford, J. (2017). An investigation into the development of the absorptive capacity of manufacturing SMEs. International Journal of Production Research, 55(23), 6916-6931.

[64] Sahir, S. H., \& Rosmawati, R. (2020). Improve Marketing Mix for Marketing Plan Strategic in Coffeeshop Business. Management Analysis Journal, 9(4), 459-466.

[65] Samašonok, K., Išoraitè, M., \& Leškienè-Hussey, B. (2016). The internet entrepreneurship: opportunities and problems. Entrepreneurship and Sustainability Issues, 3, 329-349.

[66] Sarker, T. R., \& Al Saeed, L. S. L. A. (2020). Benchmarking Marketing and Business Strategy of UNIQLO to Start-up a Retail Shop in Bangladesh. Benchmarking, 12(2).

[67] Sepeai, N., \& Ramli, Z. (2019). Pengurusan Kewangan Usahawan: Kajian Kes Usahawan KADA di Kota Bahru, Kelantan. Jurnal Wacana Sarjana, 3(3), 1-13. (Kewangan).

[68] Singh, R. K., Luthra, S., Mangla, S. K., \& Uniyal, S. (2019). Applications of information and communication technology for sustainable growth of SMEs in India food industry. Resources, Conservation and Recycling, 147, 10-18.

[69] Smith, A., \& Hayton, G. (1999). What drives enterprise training? Evidence from Australia. International journal of human resource management, 10(2), 251-272.

[70] Suseno, Y., Bao, C., Baimbridge, M., \& Su, C. (2019). Informal training in Chinese small-and medium-sized enterprises. International Journal of Entrepreneurship and Small Business, 37(1), 1-24.

[71] Teklehaimanot, M. L., Ingenbleek, P. T., Tessema, W. K., \& van Trijp, H. C. (2017). Moving Toward New Horizons for Marketing Education: Designing a Marketing Training for the Poor in Developing and Emerging Markets. Journal of Marketing Education, 39(1), 47-60.

[72] Ubfal, D., Arraiz, I., Beuermann, D. W., Frese, M., Maffioli, A., \& Verch, D. (2019). The Impact of Soft-Skills Training for Entrepreneurs in Jamaica. Available at SSRN 3374406.

[73] Vancell, J. (2018). e-Learning for older workers in SMEs?: the perceptions of owners and workers in Maltese microenterprises.

[74] Vandenberg, P., Yoshino, N., Goto, A., Intarakumnerd, P., \& Miyamoto60, J. (2016). Policies to enhance SME internationalization. Integrating SMEs into Global Value Chains, 117.

[75] Vazirani, N. (2010). Review paper: Competencies and competency model-A brief overview of its development and application. SIES Journal of management, 7(1), 121-131. 
[76] Yasmin, A., Tasneem, S., \& Fatema, K. (2015). Effectiveness of digital marketing in the challenging age: An empirical study. International Journal of Management Science and Business Administration, 1(5), 6980.

[77] Youssef, A. B., Boubaker, S., \& Omri, A. (2018). Entrepreneurship and sustainability: The need for innovative and institutional solutions. Technological Forecasting and Social Change, 129, 232-241.

[78] Zaidan, E. (2017). Analysis of ICT usage patterns, benefits and barriers in tourism SMEs in the Middle Eastern countries: The case of Dubai in UAE. Journal of Vacation Marketing, 23(3), 248-263.

[79] Zaimah, R., \& Abdullah, S. (2017). Tahap keupayaan usahawan dalam Perusahaan Kecil dan Sederhana di Kuala Terengganu (The entrepreneurs' capability level in the Small and Medium Enterprises in Kuala Terengganu). Geografia-Malaysian Journal of Society and Space, 13(4).

[80] Zain, R. M., \& Ramli, A. (2020). Model Permasalahan Kesesakan Trak di Depoh Kontena Kosong: Kesahan Melalui Teknik Delphi. Journal of Information System and Technology Management, 5 (16), 35-49.
[81] Zainol, A. S., \& Ramli, Z. (2019). Pengurusan Kewangan Usahawan MADA: Kajian Kes di Kubang Pasu, Kedah. Jurnal Wacana Sarjana, 3(4), 1-10.

[82] Zakaria, N. A. M., Hamid, M. A. A., Norazman, I., \& Thukiman, K. (2020). Pengalaman Pembelajaran Informal Dalam Kalangan Usahawan Bumiputera Perusahaan Kecil Dan Sederhana (Pks) Di Besut, Terengganu. Jurnal Kemanusiaan, 18(2).

[83] Zakaria, N., Zainal, S. R. M., \& Nasurdin, A. M. (2011). Investigating the role of human resource management practices on the performance of SME: A conceptual framework. Journal of global management, 3(1), 7492.

[84] Zaman, M. M. K., \& Othman, N. (2019). Amalan Pengurusan Perniagaan Usahawan Wanita Felcra Berhad. Journal of Business Innovation, 3(1), 1.

[85] Zulkarnain, E. F., Abdullah, A. N. F. B., \& Ridzuan, A. A. (2019). Tahap Pendigitalan Perniagaan Dalam Kalangan Usahawan PKS MARA di Melaka. Politeknik \& Kolej Komuniti Journal of Life Long Learning, 3(1), 130-140. 